（モニタリング）

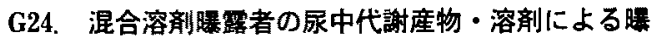
露の評洒

緒方正名（川崎医療福祉大）

G25. 有機溶剂作業者の飲酒習慣が尿中代謝産物に及 ほす影翠

大城康一 (山口大医公衛) ほか

G26. 1，1１-トリクロルエタン䎬露の指標としての尿 中溶剂灌度と尿中代謝物湢度

水沼一典（中災防大阪センター）ほ加

G27. エチルベンゼン，トルエン，キシレン混合曝露 労働者における㖟煙、飲酒習慣による尿中マン デル酸排泄の修飾

井上 修 (東北労災) ほ力

座長：河合俊夫（中災防大阪センター）

G 24. 作業者の尿中排泄㗳度評価方法を考察され，3 つの場合について 1）全成分の尿中排泄物濃度より,

2）一部の成分の尿中排泄物濃度か BEI の測定例の無 (時, 許容濃度上りの補完法. 3) 测定成分のみで評価 する方法を説明された，3）の場合に嚗露濃度>尿中排 泄浱度の值（曝露濃度・尿中排泄濃度の値）については， 理論的検討の他に㬰際の作業場の例を数多く集め統計的 な処理をする必要があるとのことであった。

G 25. 有機溶剤作業者の飲酒習慣泳中代謝物（尿中 馬尿酸）に及济影響を調へている. 男子 544 名, 女子 135 名の検查結果を，アルコールと尿中馬尿酸，アル コールと肝機能，尿中馬尿酸量の季節変動，作業規模之 血液系值の関係にっいて整理された，毎日の飲酒（1 合 -2 合）で馬尿酸量が低くなる. 質問は夕バコ之の関係， 作業者の年龄などについてであった．年齢は 40 歳と 50 歳台が殆んどであり，タバコとの関係は今後検討すると のことであった。

G 26. 1, 1, 1・トリクロロエタン（MC）の曝露濃度と 尿中溶郕，代謝物についての報告で，尿中溶剂の測定は 曝露指標として特異性があり，測定方法も簡便であるこ とから MC 瀑露の指標に有用であると報告された，尿 中代謝物や尿中溶剂測定檤補正の有用性についての質問 があったここの補正については統一的な見解はないが， 我々はいつす尿比重補正 (1.016), クレアチニン補正, 測定値 (非補正)を抗こなっているとのことであった。

G 27. エチルベンゼン，キシレン，トルエン混合曝露 学㗢者における孯煙，飲酒習慣による尿中マンデル酸は 唤煙により代謝抑制がみられると報告された，質問は同 し曝露指標であるスチレンの場合は㧕制があるか，また 回㷌式の切片に非契煙と契煙群およびその他の群の間に 差があるのではないか，などがあった，スチレン代謝の 抑制は今後検討する．切片は有意差かなく同じ様な曝露 群と考えてよいとのことであった。

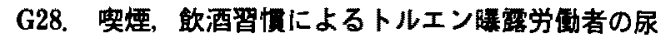
中 0-クレソール排泄修飾

清治和則（東北労災）ほか

G29. 低浱度トルェン䀧露作業者の尿中馬尿酸，血 中・尿中トルエン漕度

问合俊夫（中災防大阪センター）

G30. 有機溶剂取扱い作業者の生物学的モニタリング 一尿中馬尿酸検査によるトルエン䀧露評価の実 践的検討一

吳羽晃德（香川労災）ほ ほ

G31. トルエン、メチルアルコール，酢酸メチル低浱 度混合璂露時におけるスチレン作業者尿中代謝 物の排泄

張 作文 (京大医公衛) ほ加 座長：田口豊郁（川崎医療福祉大）

G 28，喫煙と飲酒がトルエン暴露者の尿中 o-クレ ゾール排出を修飾するかを検討した報告である.トルエ 嚗露者および非暴露者を(泇煙，饮酒）の習慣によっ $\tau$, (1) $(-,-)$, (2) $(+,-)$, (3) $(-,+)$, (4) $(+$, 十）の 4 群に分け, トルエンの暴露濃度と尿中0-クレ ゾール漂度の回帰直線の切片之勾配の差の検定から，(1) と比べて，(2)く(3)《(4)の順に抑制効果が大となったと報 告した，BEI の使用に当たって咽煙，领酒を考虑する必 要があると共同研究者から追加があった。

G 29. 低濃度トルエン暴露の生物学的モニタリング指 標として何が優れているかを検討した報告である、トル エン暴露濃度と生体試料浱度の“相関係数”之“并別可 能濃度”から，指標としての優劣を判断し，血中卜ルエ ンおよび尿中トルエンが低濃度トルエン暴露の生物学的 暴露指標として有用であることを報告した，血中トルエ ンの測定法について質問があり，ヘッドスペースガスク ロマトグラフ法で測定しているとの返答があった。

G 30. 尿中馬尿酸の測定を労衝衛生管理に利用した報 告である．就業時間中に排尿ごとに採尿し，時間排泄量， 時間加重, 平均濃度, 作業後濃度, 最大濃度で表した。 時間排泄量と漂度表示法別の相関をるるとクレアチニン 補正の相関加最も良加った。作蕀環境測定結果, 個人暴 露濃度, 尿中馬尿酸濃度を比較すると, 各测定值の差異 が作業内容の違いによると，理由付けすることができ， 作業環境管理および作業管理上の示唆を得ることができ たと報告した.

G 31、スチレンとトルエン、メタノール，酶酸メチル の混合暴露の場合, 尿中マンデル酸およびフェニルグリ オキシル酸浱度がスチレン単独暴露と比較して抑制され るかを検討した報告である，スチレン暴露湌度と尿中代 謝物濃度の回㷌式の傾きの差の検定から，今回のような 低濃度暴露では，両代謝物とも非泄には有意な変化か認 
められなかった之報告した，調查工場についての質問が あり，ボタン製造工場で，トルエン以外は洗浄溶䯇であ ると返答があった。

G32. メチルエチルケトン取扱い作業者の個人暴罟湿 度と生物学的モニタリンダ

吉川正博（産医大医短）ほか

G33. MEK、アセトンあるいはトルエン同時暴露が 血液，神経，尿中 2,5-ヘキサンジオン皘度に 及ぼす影響

趙 文元（大分医大公衛 2 ）ほか

G34、検出器に FTD を用いたガスクロマトグラフ法 による尿中 2,5-ヘキサンジオンの分析

田口豊郁（川崎医療福祉大）

G35. 血中・尿中メタノール定量法の比较検討

文 喍錫（京大医公衞）ほ加 座長：川本伐弘（産医大衛生）

G 32.メチルエチルケトン（MEK）取扱い作業者の MEK 個人曝露濃度と血中，尿中 MEK 濃度之の関係を 調べたものである. 血中, 尿中 MEK 濃度はともに個人 曝露濃度と良好な相関を示し，尿中 MEK の BEI は 5.1 $\mathrm{mg} / l$ と算出された，日本における調查結果は，他国と 比べて BEI が高く，民族差，作業負荷の差，共存する 有機溶剂の影響等が示唆されたとのことであった。

G 33. 2,5-ヘキサンジォン（HD）とメチルエチルケ トン（MEK），アセトンあるいはトルェンとの同時皮下 投与を行い，血清，神経および尿中 $\mathrm{HD}$ 濃度の変化を 調ベたものである，HDの血清抽よび神経中クリアラン スは, 単独投与群にくらべて, 混合投与群では著明に遅 くなっていたが, 同じモル数の投与ならば，溶剂の種類 （MEK，アセトン，トルエン）にかかわらず，血清およ び神経中濃度,クリアランスに差は認めなかったとのこ とであった。

G 34. 2,5-ヘキサンジオン（HD）をピロール化し，2， 5-ジメチルピロール (DMP) としてFTDで高感度かつ 選択的に定量することを演者らはすでに発表しているが， 今回はそのピロール化（アルカり加熱）過程によるHD 測定值に対する影響を調べたるのである. 結果としてア ルカリ加熱による影響は無視できたので，ピロール化 GC-FTD 法は加水分解なしの 2, 5-ヘキサンジオンの測 定に対処できるとのことであった。

G 35. 血中书よび尿中メ夕ノールの測定について，ガ スクロマトグラフ、へッドスペース法（DB-WAXカラ 么使用）および直接注入法（DB-WAX と TPA SBS100 の 2 種のカラムを使用）を比較検討したものである. 結果として，血液・尿ともに直接法では回収率不良また は変動係数高值の問題があり，污染によるカラムの保守 上の問題もあるためへッドスペース法が最も優れている
とのことであった。

G36. トリクロロエチレン中毒における血中, 尿中ト リクロロエタノールとトリクロロ酶酸の推移

吉田 稔（聖マリアンナ医大公衛）ほか

G37. メチルペンタン取级い作業者の尿中代謝物 八杉友次郎（中災防中四国センター， 京大医公衛）ほ加

G38. 有機溶剂の代謝相互抑制一代謝され易い溶剂と 代謝され難い溶剂をモテル物質として

金子 誉 (山梨医大保健 1) ほか

G39. アスピリンと $\mathrm{m}$-キシレンの代謝相互作用に関 するシミュレーションモテル

遠藤和志 (山梨医大保健 1) ほか 座長：坂井 公 (東京労災)

G 36. 池田（京大・公衛）は中毒事例として，同样な 尿中排泄の推移を経験していることを追加した，尿中濃 度についての質問には，事故 8 時間後で， $326 \mathrm{mg} / l$ で あったとの答えで, 尿中排墈の図 2 纯図 3 と訂正され, 加縦軸の单位は $\mathrm{mg} / \mathrm{day}$ 之訂正された。尿中濃度は 輸液の影響で相当薄まっていることが考えられるとの追 加ああった，尿中の TCE と TCA の量此についての質 問には，事故1日目には $75 \%$ が TCEであったという。

G 37. メチルペンタンの尿中代謝物をラットと作業者 で比較して, 両者で同様な結果を得，作業者では個人曝 露濃度とほぼ対応する結果を報告した。 メチルペンタン の用途についての質問には，1タリアでへキサンを除い た溶郕として接着に利用されていたものであるとの回答 であった，加水分解の条件についての質問には，基本的 にはへキサンジオンのそれと同じであるが，䤃素量は 5 倍量必要であったとの答えである。

G 38. 有機溶剂の体内動態と代謝相互作用の関連につ いて，動物を用いた検討である，代謝され易い溶剂どう しの場合には許容濃度以下では相互㧕制がみられないが, 一方が代謝され難い場合には低濃度でも抑制㑯向が認め られるとの報告である，溶刜溇度決定理由についての質 問には，許容濃度以下と，その10 倍濃度としたとの解 答であった：そのほか，動物での結果を作業者に当ては める方向での研究を期待するとの要望があった。

G 39. 頭痛薬を服用しながらの浴剂作業は現実にあり 得ることでここれを想定して生物学的モニタリング値が どのように修飾されるかをシミュレーションした報告で ある. アスピリンの 1 日用量程度の服用で， $100 \mathrm{ppm}$ のキシレン作業をすると, グリシン抱合活性の違いによ り，人によってメチル馬尿酸値として $15 \%$ 程度の差が 生じることになるという。

\section{G40. 有機溶剤の経皮吸収に関する基䊙的研究}


弥富美奈子（佐賀医大地域保健）ほか

G41. CYP 2 E 1 およびGSTM 1 多型とエチレングリ コールモノエチルエーテルアセテート尿中代謝 物との関係

坂井 公 (東京労災) ほ

G42、ALDH 2 遗伝子型とヒト肝における多種類ア ルデヒドの代謝

王 瑞生（産医研）ほか

G43、DNA 多型と生物学的モニタリングー4 . ALDH 2 多型と飲酒習慣一

川本俊弘（産医大衛生）ほ

座長：那須（中島）民江（信大医衛生）

G 40.トルエンの経皮吸収動態を血中トルエン濃度か ら検討した報告である，有機溶郕の経皮吸収に関する研 究は少ないので重要な報告である（産医研鶴田）が，中 毒学的にみた場合に経皮吸収の重要性はあるか（京大池

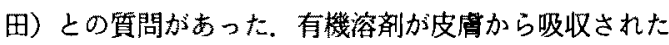
場合，血中濃度が高くてあ代謝物量は経気道吸収より少 なく，両者における体内動態が異なることを考慮する必 要性 (山梨医大侤藤) のコメントがあった。

G 41. エチレングリコールモ/ェチルエーテルアセ テートの生物学モニタリングに対する CYP 2 E 1 上 GSTM 1 遺伝子多型の影響の報告である。これらの酵 素や他の䤃素分子種の対象溶戍の代謝への関与に対する 質問（産医咞王）に対しては現在不明との回答であった。 分子生物学か谁歩した今日，このような疫学調查に加え て，その意義付けの実験的研究も重要であろう.

G 42. アルデヒド脱水素醇素 2(ALDH 2) の遺伝子 多型と種々のアルデヒド類の代謝に関する研究報告であ る. 代謝速度を測定する際アルデヒドの揮発性が問題に ならないか（中災防河合）との質問に対して「問題な し」との回答が，可溶性分画の活性值が細胞全体の値を 示すか（京大池田）との質問に対して「アセトアルデヒ ド代謝に対しては可である」との応答があった，山梨医 大遠藤より細胞分画の方法に関しての質問があった。

G 43. ALDH 2 遗伝子多型とトルエンの生物学モ二夕 リング，および飲酒・喫煙の影響に関する報告である。

喫煙者の多くは飲酒習慣をむっており，それぞれのみの 影響の評価は難しいが，飲酒・喫煙は馬尿酸の排泄を抑 制する (京大沏田). しかし生理的シミュレーションか ら考えると，低蕽度有機溶剤暴露では血流量が代謝を律 速するので，代謝酵素の影響はないのでは（山梨医大佐 藤）とコメントがあった。

(無機物)

H 1. フッ化物中毒時におけるヒドロキシアバタイト の吸着剂としての効果

近藤 武（松本歯大口腔衛生）ほか
H 2. フッ化水素系表面処理剂吸入による肺障害の処 置法之労帪衛生管理について 河野公一（大阪医大衛公衛）ほ

H 3. 毛髮中フッ素湿度について（第 2 報） 板井一好（岩手医大衛公衛）ほか

H 4. オゾン暴露に対するラットの呼吸および肺外反 応の加齢性変化

有藤平八郎 (産医研) ほ加 座長：日下幸則（福井医大環境）

H 1．フッ化物中毒の吸着剤として開発された，合成 ヒドロキシアパタイトの效果を動物実験で確かめた研究 である、虫歯予防のうがい薬を誤って食べた場合に見ら れる中毒などに効を奏すと思われる，NaF の投与 30 分 位でフッ素は血中に移行するので，その頃の HApがよ り適切であろうとの演者の追加コメントがあった.この $\mathrm{NaF}$ 投与ラットでフッ素の蓄積があり，そのための腎 障害む考元られるとの指摘がなされた。

H 2. フッ化水素酸を含む表面处理剂を，マスクも付 けずに塗布した為、重篤な間質性肺炎を来したが、グル コン酸カルシウムの吸入で救命し得た，貫重な症例であ る.これまで 5 例の死亡事故が文献的に報告されている が, 救命したのは初めてのことと演者から追加コメント されたその曝露濃度は，高温のせいもあって数百 ppmになっていたと想像され，ガス状になっていたり， 他のヒュームによる複合影響むあったらしい。

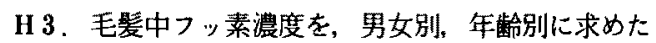
労作の研究である，女性の，しか向高齢者でその濃度が 高いことの意義に関して質問が集中した。毛髪はつッ素 の排泄経路の 1 つであるが，その意義について確たる説 明は得られなかった，髪の洗浄方法が工夫され，また黒 い部分と白髪の部分での濃度差はなかったとのことであ る.

H 4 、現行の許容濃度である $0.1 \mathrm{ppm}$ 位のオゾン曝露 で，呼吸循環系の変化が，しかる高数ラットよりも若齢 ラットに顕著に現れたとの研究報告である.心拍数低下， 分換気量低下がそれであるが、他に体蕰低下，睡眠誘発 もあったので, 有害影響を軽減する，何らかの防御機構 と演者により解釈された．この程度の濃度であ気道系の 形態学的変化があるとのコメントがあった. C-FIBRE への直接刺激がメカニズムとして考えられていた。

(他の有機物)

H 9. 松本市で発生した有毒ガスによる被災者救出作 業者の被災について

那須 (中島) 民江（信大医衛生）ほ

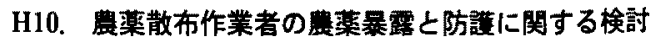
一ハウスキュウリヘのベルメトリン散布作業を 例として一 
浅川冨美雪（香川医大衛公衛）ほ力

H11. O, O, S-trimethylphosphorothioate (OOSTMP）投与後の細胞死一肺毒性リンパ器官萎 緶における役割一

小泉昭夫（秋田大医衛生）ほ加

H12. ヘキサクロロフェンのヒト赤血球膜に及ぼす影

松村浩彦（産医大産生研環境中毒）ほ加

座長：香川 順（東女医大衛生）

H 9，追跡調查結果に関する質疑に対して，眼の波れ を訴えるものが最す多く，堌加傾向がみられたこと，ま た，四肢のシビレを訴えるものもみられたとの回答で あった，風向などで計算し難いだろうが，発症率は，大 体どの位功と質疑に対しては，一応調べているとの事 で、後日発表したいとの事であった。

H 10．防じんマスクの装着の効果があったとの事で あるが，不快感の訴えはなかったかの質疑に対しては， ないとの事であった，調査1の低下が悪いのは，フロに 入らないため経皮吸収があったのではないかとの質疑に 対しては，フロに入っていたと思われ，原因はよく分ら ないとの事であった，半隇期が長いようにみえるがとの 質疑に対しては，よく分らないとの事であった。

H 11. OOS-TMPは，有機りン製造時に一般的に不 純物として入ってくるもの加との質疑に対しては， 5 ppm 以下との事であった. Programmed cell deathの 発生機構に関する質疑に対しては，Ca 代謝が関与して いるらしいとの事であった，呼吸器にどのような病状を おこすのか，又，日本で発生事例があるのかとの質疑に 対しては, Chemical Pneumonitisでパキスタンで発生 したが、日本では啹告されていないとの事であった。

H 12. へキサクロロフェンは，使用禁止になってい るとの事であるが、そのような物質の生体影響を調べる 理由は何功と質疑に対しては，神経毒性の機構を調べ るためであるとの事であった．赤血球膜 AchE 阻害が 神経毒性の発生に関与しているのかとの質疑に対しては, その可能性が示唆されるとの事であった。

H13、沃化メチルによる高脂血作用に関する実験的研 究

大谷勝己（産医研）ほか

H14. ニトログリコールのSHR ラット摘出心筋に対 する作用

田井鉄男（産医研）ほか

H15，感光性樹脂板製造における職業性角膜炎

原 一郎（大阪勤労者健康サービス）ほ加

座長：小泉昭夫（秋田大医衛生）

H 13. 沃化メチルがヒトにおいて，高脂血症を有す る事から曝露影響評価の指標として血性脂質の変動を用
いる事が出来るかどうか検討したものである，高濃度投 与群で高頻度に死亡が生じている事より毒性メカニズム についての質疑があった，演者証，沃化メチルの毒性に 対する感受性は，加龄によって著しく增加する事を追加 し，今後の検討を約した，非常に興味深い知見であり， 今後の発展が期待された。

H 14. 二トログリコールによる毒性は，従来血管収 縮の点から検討されて来たが，本報告では，心筋収縮力 について検討し，ニトログリコールによる等死に対し 新機軸から换討を試みたものである。心収縮力は主とし て $\mathrm{C}_{\mathrm{a}}^{*}$ に関連した機能であり，致死性の不整脈の発生に 関連したパラメターは，静止脈電位之関連する点が討論 で指摘され，突然死亡の関連か議論された，今後心収縮 力以外の評価む行い，実験系の確立が期待された。

H 15. ハイドロキシェチルメタアクリレート蒸気曝 露による角膜炎の症例を 2 例呈示し，同一職場での眼科 検診の結果高頻度に眼障害か認められた事を報告した。 本物質は多くの印刷作業関連あるいは半導体産業などで 現在す使用されているが，現在まで報告と同椂の事例は 少なく、見過しによる潜在例の存在が示唆された。自治 医大・山口より光過敏性について質問があった．演者も UV の影響の可能性を否定出来ない上汒答した.

（アレルギー）

H24. 建設労㗢者に発生した職業喘息の四例 藤井正實（東京社医研センター）ほか

H25. 環気中の酸無水物の測定について（第 2 報）

城山 康（松下産衛センター），は加

H26. 電子部品製造工程における算炎と免疫血清学的 検查について

山口恭平（松下産衛センター）ほか

H27. 職業性ユスリカ（昆虫）アレルギーの原因抗原 について

寺西秀豊（富山医薬大公衛）ほか

座長：吉田 勉（藤田保衛大医公衛）

H 24. 建設労働者（主に大工）を主体とした職業起 因性喘息症例の検討.レセプトから堀りおこすという大 变に困難な調查にもかかわらず, 具体的に症例として絞 りこんだ点は評価できる。しかし，症例の臨床的検討で は，(1)米杉，米松等の自家製抗原液の作成上の信頼性の 問題. (2)判定基準などについて，さらに検討が必要であ ることが指適された。

H 25. コンデンサ製造工程での酸無水物の測定につ いて $0.1 \mathrm{ppb}$ レベルまで短時間で精度の良い方法を確立 した。これにより，エポキシ樹脂・硬化剂を使用してい る現場における作業環境湘定による評洒・改善がより具 体的に実施できることが期待される.今回は定常作業に よる測定結果の報告が行なわれたが, 今後非定常作業時 
の測定結果，その他の感作性物質の測定などを含めた総 合的な環境評価についての恰討が望まれることが指摘さ れた.

H 26. 感作性をもつ硬化郕として知られるメチルテ トラヒド無水フタル酸（MTHPA）暴露作業者 22 名 を対象とし，H-25の演題で測定した暴露濃度との関連 ならびに特異的 IgE 抗体の検出が試みられた。特異的 $\operatorname{IgE}$ 抗体では，鼻炎症状との関連で症状のある 2 名に特 異的 IgE 抗体が陽性であった，本報告は，MTHPAの 許容濃度の検討に大きな示唆を与えると考えられるが， 今後その他の感作源や経皮感作等についての検討が望ま れる.

H 27、ユスリカ（幼虫は鈎のエサとして知られるア カムシ・アカボウフラ) アレルギーの原因抗原の検討を SDS 電気泳動之転写後のIgE抗体との反応により行っ た. ユスリカ奻蚢原では，10 KD 前後のへモグロビ ン分画が，一方ュスリカ成虫抗原では $10 \mathrm{KD}$ 以外にも, $25 \mathrm{KD}$ から $67 \mathrm{KD}$ の広い範团で反応が認められ，成虫 ではへモグロビン分画以外の特異抗原の存在が示唆され た。ニスリカは日本各地で大発生しており, 注意が必要 である.

H28. 農藥暴露作業者のリンパ球サブセット及び SCEについて

川見正機（労研）ほか

H29. いちしく栽培作業による職業性皮庫障害（II）

西谷宣雄（大阪勤労者健康サービス）ほか

H30. 接触感作マウスの in vivo サイトカイン産生の RT-PCR 法による検出

胥 宝会（鹿大医衛生）你

H31. 接触感作マウスのリンパ球内のカルシウム浱度 の変動

青山公治（鹿大医衛生）ほ加 座長：上田 厚（熊本大医衛生）

H 28. 農業従事者, 白礒駆除作業者，対照群につい て、末梢血リンバ球サブセット，SCEを測定し，農薬 曝露による免疫系への影響，細胞遭伝学的影響が検討さ れた，対象 2 群における㳑煙者 SCEの上昇，リンパ球 サブセットの多彩な変動が認められた。これに対し，湘 定時期, 採血洔期の設定には䈌密な配度が必要なこと, いくつかの実験例が質疑された。

H 29. いちじく栽培農家を対象に，作業内容と皮消 症状発症に関する質問紙調查と皮痛検診が実施された。

皮唐症状は芽加き（5，6月），収稪期(8，9月）に急增 する傾问がみられた。 7 症例について 1 年目上 3 年目の 皮症症忞化が追跡され，予防，治療の差異が経過に 差をあたらしていることが示唆された，発症機序（一次 刺激, 感作性, 光過敏性) や, 手袋の材質と着用指導な
どについて質疑がおこなわれた。

H 30. DNCBによる接触皮譄炎マウスの脾埛におけ る in vivoのサイトカイン産生， RT-PCR 法を用いた サイトカインの in RNA 剣出により評価された，接触 皮庙资マウス，対照群のいずれにも IL-4，10，IL-2， INF- $r$ が検出されたがとくにINF- $\gamma$ in RNA が皮届炎マ ウスに有意であった。 また，IL-12 in RNA の增加が接 触アレルギー皮唐炎にお讨るTh1細胞の誘導に関与し ている可能性が示唆された。 in RNAの测定時期 （phase）などが質疑された。

H 31．八プテンまたはPHA に対する感作マウスのリ ン八球内の $\mathrm{Ca}$ 濃度の測定により，感作物質の in vitro 評価における有用性が検討された，その結果，接触感作 されたマウスのリンパ球は非感作マウスのそれより PHAに対し浮性化されやすいことが示されたが, 感作 性の評価における Ca 濃度測定については今後さらに方 法論を含むいくつかの検討が必要とされた。感作物質の 反応予測を検索するための有用な方法として今後の発展 が期待される。

\section{金 属 等}

(鈆)

J 1. 鉛精鍊作業者の腎機能異常：量一影噌，量一反応 関係

野見山一生（自治医大衛生）ほ加

J 2、鉛精錬作業者の造血系障害：量一影響，量一反応 関係

劉 揚（自治医大衛生・中国医大

環境衛生)ほ加

J 3. 鉛精鍊作業者の血压 : 量一影䈉, 量一反応関係

野見山紘子(自治医大衛生)ほ

J 4. 鉛作業者における血液中鉛と血墏及ひ尿中 ALA との関連

大石浩隆（佐賀医大地域保健）ほか

座長：横山和仁 (東大医公衞)

J 1 - 3. 中国男子鈶精練作業者（血中鈶 $99 \mu \mathrm{g} / \mathrm{d} l$ 以 下）で検討された，腎機能，造血系及び血圧に及ぼす鉛 の影響の量一影響及び反応関係が野見山（自治医大）ら により報告された（それぞれJ1，2及び3）。同一対象 集団での関連ある研究報告であったため，質疑は一括し て行なわれた。これらに対し, 福島 (古河電池) 上り, 現在の血中鈶レベルにもとづく量-反応関係 (Hernberg 等）が一般に知られているが，過去の暴露レベルまたは 暴露年数がこれを修飾するか否か質問があり, 過去の暴 露レベル及び年数の皘，最高值等の検討も必要であろう との回答があった．また，斉藤（東海健診センター）上 り鋂仙痛の出現レベルが尋かられ，過去の暴露歴によっ 
ては一般に言われているよりも低い血中鉛（現在）レベ ルでみられる可能性があると回答があった，さらに，干 葉（㮌天大）より，遗伝的な低 ALAD 活性者加低暴露 レベルの量-影響（反応）関係に及ぼす影響が指摘され たがそのような者の頻度は低いため影響は小さいであ ろうと回答があった，以上のほか，中国における環境評 価，健康管理システムに関して質疑があった。

J 4 、血漿及び尿中 ALA は血中鉊之高い相関をもつ との報告が大石（佐賀医大）らよりあった。こてれに対し， 細田（慶応大）及び千葉（順天大）上り調查地域が赤标 られ、中国 (北京, 潘陽) での調查でありかつ大気污染 のためコントロールの血中鉛も高めであることが回答さ れた，さらに，座長より低血中鉛レべルでの血墏・尿中 ALA の量-影響 （反応）関係の解析の必要性が指摘さ れた.

\section{J 5. 铅作業者血中の主要および唡量元素浱度}

干葉百子（順天堂大医衛生）ほか

J 6. 鉛暴露作業者の低分子タンパク尿所見

清田郁子（大阪市大医環境衛生）ほ

J 7. 鉛が身体平衡機能に及ぼす影筫一年龄，身長お よび体重の影響の検討を含む

横山和仁（東大医公衛）活加

J 8. 作業愣境における鉛吸入性粒子の個人曝露皘度 之血液中鋁漂度との関係

小田健一（慶大医衛公衛）ほか

座長：野見山紘子（自治医大衛生）

J 5.MIP-MAS による路作業者の血策中，血球中元 素の測定結果を示した，鉛作業者数に対して，対照者数 が少ない点（佐賀医大，友国）については，同一職場を 選んだためと回答された．MIP-MASによる生体試料測 定の展望（自治医大，野見山）については，感度，技術， コスト面であ今後期待できると回答された。

J 6. 鈶嚗露作業者の低分子蛋白尿所見について，尿 中 $\beta_{2}-\mathrm{MG}$ の分布（慶底大，小野寺）については対数正 規分布であったと回答された．また，1．低分子蛋白だ けでなく蛋白, 糖、アミ/酸の測定が必要，2. 年齢が $22-78$ 歳の場合のクレアチニン補正の問題， 3 ，尿中 NAG 測定の問題，4，尿細管の機能異常を論じるには 低分子蛋白の值か低すぎる等（自治医大，野見山）のコ メントがあり，大阪市大，圓藤より検討中である旨回答 された。

J 7. 捈曝露と身体平衡機能, 年齢, 身長, 体重の影 響を検討したところ血中鈶 $50 \mu \mathrm{g} / \mathrm{d} l$ 以下の鉛作業者に より非顕性の平衡機能障害の存在が示されたことを報告 した，身体平衡機能が大きく変化する年龄であるか（自 治医大，野見山）については，検討していないが特に大 きく変化する年䶘はないと思うと回答された：この運搬
可能な平衡機能計を用いてさらなる研究の発展が望まれ る.

J 8，吸入性鉊粒子濃度之血中鈶濃度之の関係につい て, 1. 作業環境サンプリング点 (1点のみ) が不足し ていること，2，吸入性，非吸入性粒子に分けないで トータルで見てよいのではないか（中災防，雵田）は，

1. 測定点が代表する1点であった，2，吸入性鈶濃度

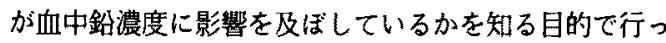
たと回答された．鈶粒子の分粒の祭，アンダーセンサン プラーで測定することの問題点（松下，高橋）を指摘し た.

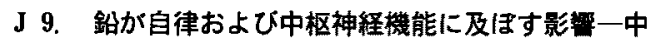
国の女子ガラス細工作業者の解析

村田勝敬（東大医公衛）ほか

J10. ポルフィリン代詂関連醭素活性に及ぽす保存状

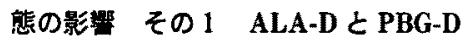

網中雅仁（聖マリアンナ医大衛生）ほ加

J11. FEP 測定における蛍光光度法と蛍光 HPLC 法 との比較 (その2)

品川興造（大阪市大医環境衛生）ほか

J12. CaEDTAの点滴静注が免疫系、へム代謝およ びピリミジン5'-ヌクレオチダーゼ活性に及ほ す影慉一鉛作業者における観察

佐田文宏（東大医公衛）ほか

座長：千葉百子（順天堂大医衛生）

J9.ヒトの自律および中枢神経機能に及ぼす鈶の影 響を明らかにする目的で行われた，自律神経機能は視 覚・聴覚神経機能より鉛影響を受计易いことを心電図を 使って明らかにした，自律神経影響は副交感より交感神 経で強く顕われる可能性を示唆した，被験者は中国人女 性 (平均血中鉛 $55.6 \mu \mathrm{g} / \mathrm{d} l$ ). 発表者は以前に $\mathrm{Pb}, \mathrm{Zn}$, $\mathrm{Cu}$ 混合暴露の日本人男性で同様の実伢を行ったが，今 回鈶単独曝露で鈆の影響をより鮮明にすることができた.

J 10. 血中の ALA-D と PBG.D (両者ともへム合成に 関与する醉素）の採血後の保存について検討を行った。 ALA-D はSH 醉素であるので DDT を添加して+5 ${ }^{\circ} \mathrm{C}$,

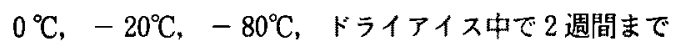
失活しない，このことは健康人とポルィリア（AIP とVP）患者とで同じ結果であった，PBG-D は保存温 度より保存時間による要因汃大きい。

J 11. 鉛作業者の血中 FEP の測定を溶媒抽出-蛍光法 と HPLC-蛍光法とで行い比較検討した， ZnPP，PPを 分別定量し総 FEP を算出すると 3 ポルフィリン体共に 而測定法の相関は非常に高い：しかし溶媒抽出法で酸抽 出し総 FEP を直接测定した結果は分別定量して求めた 值より1割程度低い：また分別定量から求めた FEP 值 は HPLC 法の方が常に高值を示す。このことは他の測 
定機関（フロアからの発言）でも同様の結果であり，検 討が必要である。

J 12. 鉛作業により労災認定を受けた 2 名の男性忠者 にCaEDTA を点滴静注し，鈆誘発を行う過程で血中鈆, へム代謝および免疫学的指標を測定した. 合計 16 週間 のキレート剂投与により血中鈶，へム代謝指標は両者で 非常に改善され，兔疫指標も IgDは両者で, IgG, IgA, $\operatorname{IgM}$ は鉛負荷のより大であった患者で有意な改善がみ られた、各パラメータの経時的変化を患者別に表示する と解り易くなり，貴重な症例なので今後に役立つと考え る.

(水銀)

$\mathrm{J} 13$. 蛍光灯敏造業における金属水銀暴露と尿中水銀 涱度の関係

宮上浩史（松下産衛センター）ほか

J14，蛍光灯製造業における金属水銀暴露者の尿中水 銀濃度と尿中 $\mathrm{N}$-acetyl- $\beta$-glucosaminidase 活 性の関係

井殿雅子（松下電子岡山）ほ加

J15. 水銀取扱者の生体試料中水銀浱度の時間的変化 一線形比较による挨討一

石原信夫（東北労災）

J16. 無機水銀の高血圧ラットに対する昇圧効果 高橋博樹（自治医大衛生）ほか 座長：川田智之（群馬大医公衛）

J 13. 䖝光灯製造者の個人水銀 $(\mathrm{Hg})$ 曝露量と尿中 総 $\mathrm{Hg}$ 量との関連を检討した報告である，自作したパッ シブサンプラーの测定精度の問題, および個人 $\mathrm{Hg}$ 曝露 量の割には尿中総 $\mathrm{Hg}$ 量はやや低めであるとの指摘が佐 藤先生（東北大衛生）からなされた，前者については同 一被験者に対するアクティブサンプラーでの測定結果と の間に高い相関係数が得られたとの回答であったが，相 関係数の大小は系統変動を含めた妥当性の検討には不十 分と考えられる。

J 14. Hg の生体影響を尿中 N-アセチルグルコサミ二 ダーゼ（NAG）量で行った報吡である，尿中 $\mathrm{Hg}$ 量の 生物学的許容值 $35 \mu \mathrm{g} / \mathrm{g}$ cre をカットオフ值として, い くつかの方法で换討したが，尿中 NAG 量は Hg 曝露の 有用な指標ではないと結諭つけた，沓中NAG 正常上限 值 $10 \mathrm{U} / \mathrm{g}$ cre は, 自社の健常集団から得られた值であ るとの追加発言があった，対照群設定に喫煙等の生活習 慣を十分に考慮すべきであるとの指摘が佐藤先生（東北 大衛生）からなされた。

J 15. $\mathrm{Hg}$ の生体懪露に関して, 就労前後の生体試料 中 $\mathrm{Hg}$ 量の時系列变化を評価する適切な統計学的手法の 提案がなされた、「曝露開始後いつの時点で生体試料中 $\mathrm{Hg}$ 量に变化が生じるか」を知るためには, 平均值の多
重比較のうち線形比較が望ましいと述べ，Scheffeの方 法で検定した結果， $\mathrm{Hg}$ 懪露後最初の 4 力月目ですでに 就労前に比べて血しょうおよび赤血球中 $\mathrm{Hg}$ が増加して いることを夷証した，質疑・討論は特になかった。

J 16. 無機 $\mathrm{Hg}$ の昇压作用を検討した内容である. SHR ラットでは， Hg 投与量に関係なく， Hg 非投与 (対照) 群に比べて収縮期血圧が有意に上昇したが, Wister-Kyoto ラットではその現象が見られなかったと している，無機 $\mathrm{Hg}$ の昇圧メカニズムに対する質問があ り，動脈硬化に関連する脂質代謝異常を考慮する必要か あるとの回答であった。

(カドミウム)

J17. カドミウム取り扱い作業者の耳下腺唾液中微量 元素漫度

高柳篤史（東京歯大衛生）ほ加

J18. カドミウム買露の腎胹への影警指標 川田智之（群馬大医公衛）活

J19. ロジステック・モテルを用いた尿中カドミウム 漲度と尿所見陽性率の量一反瓦関係

早野真史（千葉大医衛生）ほ加

座長：石原信夫 (東北労災)

J 17. Na 濃度だけでなく他の金属濃度む mole 単位 で表示すべきとの指摘に対しては，慣例的に質量単位が 用いられているのでそれに従ったとの解答があった。 し かし，複数の元素の測定を行うという事は，いずれは相 互作用を念頭においているのであるうから， mole 単位 で表示すべきであろう．慣例的に質量単位による表示が 行われているが，考えなおすべき時期にきていると考え る.また，検定にあたっては多重性の考虑が行われ格ば ならない.

J 18、Cd 曝露による腎障害の早期検出の指標として, 尿中の NAG 活性の測定が極めて有用であることを，実 験結果と多くの文献考察から，示したものである. 最大 の問題点の一つは，尿中NAG 活性の安定度であるが， 搨氏 4 度でおよそ1週間は安定であろうとの事であった。

J19. ロジステック・モデルのあてはめにあたって、 どのような計算方法（使用したンフトウエアの名称では ない）を用いたのか，明らかにすべきであろう。

（他の金属等）

J20. 曝露指標としての血液およひ尿中重金属碞度の 比较一 $\mathrm{Cd}, \mathrm{Ni}, \mathrm{Co}, \mathrm{Mn}-$

細田加那江（慶大医衛公衛）ほ加

J21. クロムメッ丰従事者とがん死亡〜 16 年間の追 跡調査研究

伊藤 敬（産医大産生研環境疫学）ほ加

J22. ベリリウム投与マウスにおける出産直前の血清 


\section{補体価の変動}

坂口早苗（聖マリアンナ医大衛生）ほか

J23. ポルフィリン代謝に及ぼすベリリウムの影皘—

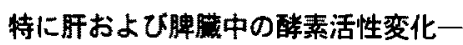

田中利明（聖マリアンナ医大衛生）ほか

座長：谷脇弘茂（藤田保嵛大医公衛）

J 20. Cd, Ni， Co， Mn 暴露作業者を対象に，職業性の 金属暴露を判断する指標として，血中及び尿中金属量を 測定し，その有効性を比較した発表であった，その結果， Cdについては血中濃度, Niについては尿中濃度, Co については測定感度の点加ら尿中濃度測定が良く、 Mn については環境濃度が低いことす関係するかもしれない が，血中・尿中のどちらの測定であ良いと考えられた。 これに対して，暴露に関連した日内変動等について質問 があった。

J21. クロムメッキ作業者とクロム以外のメッキ作業 者を対象に, 16 年㣪の 1992 年 12 月末日現在の死因調 查を行ない，各種癌死亡について標準化死亡比 (SMR) を用いて比較検討した報告であったその結果，クロム メッキ作業者の肺癌以外は有意なリスクの上昇を認めず， また従事年数の長さによるリスクの上昇は認めなかった。 これに対して，クロムメッキ作業者のクロム以外の発癌 物質との接触の関係, 詳細なデータの公表等が質疑され た.

J 22. 雌性マウスの皮下に，塩化ベリリウムを投与し た後娃娠させ，出産直前に対照群，非妊娠ベリリウム (Be) 投与群，奸娠非 $\mathrm{Be}$ 投与群，妊娠 $\mathrm{Be}$ 投与群の $\mathrm{CH}$ 50 値、 $\mathrm{ACH}$ 值, プロトロンビン（PT）時間及び血被 凝固第比因子活性を比較した報告であった。その結果, 娃娠による $\mathrm{CH} 50$ 値及び $\mathrm{ACH}$ 值の有意な低下, 妊娠 Be 投与群の PT 時間及び第VI因子活性測定における凝 固時間の短縮を認めた。これに対して，Beによる胎児 の異常等につき質疑があった。

J 23. ポルフィリン代謝に及ぼすべリリウム（Be）の 作用を調べるため，雄性マウスの皮下に塩化 Be を投与 l, 肝䑏，脾葴，血液中の ALA-D 活性値及び PBG-D 活性值について報告した，その結果 Beの影響は，肝蔵 の醅素活性に対して強く作用していることが推測された が, 肝䑏のへム合成の律速䣼素である ALA-S 活性は, 対照群より低值であり，現在検討中とのことであった。 これに対して, ALA-D・PBG.D 活性値の測定方法等に つき質疑があった。

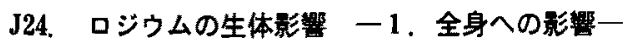
平田美由紀（九大医衛生）

J25, ロジウムの生体影部 -2 . 雄性生殖機能障 㝘-

大村 実（九大医衛生）ほ加
J26. アルキルアルシン暴露の生物学的モニタリング

山内 博（聖マリアンナ医大公衛）ほか

J27. ラット経口投与による矹素の代謝と排泄動態

臼田 寛（大阪医大衛公衛）ほか

座長：大前和幸（患大医衛公衛）

J 24。塩化ロジゥム $50 \mathrm{mg} / \mathrm{kg}$ を雄 SD ラットに腹枿 内投与し，全身影響を観察した㬰験でる．主な標的部 位は腎近位尿細管であり，投与数日で塤死および腎機能 異常, 以後再生像か観察された，山内（聖マリアンナ医 大）のロジゥム局在部位の質問に対しては，留皮質・䯣 質に濃度差のないこと，大前（慶応大）の再生像の瀻維 化の有無に対しては，見出されな加ったこと，表の腎機 能については各週秢対照ラットとの比較であること等が 質疑された。

J 25. 前報と同一ラットで，投与 3 日後に血液中テス トステロン㴗度の低下および精柴中の多数の变成 Step 19 精細胞の出現 (病理写真回覧), 2 週目に精果上体体 尾部の精子数低下か誰察された，石西（中村学園）は, 一連の変化がロジゥムではなくストレス反応によるテス トステロンの変動の結果の可能性を指摘した，大前（慶 応大）は精巣中のロジウム濃度の経時変化の質問に対し ては，変動かなかったこと，等加質疑された。

J 26. トリスジメチルアミノアルシン (TDAA), ターシャリーブチルアルシン（TBA）は空気中で容易 に酸化されること，LD 50 (皮下) 各々 $15 \mathrm{mg} / \mathrm{kg}, 48$ $\mathrm{mg} / \mathrm{kg}$, 生物学的モニタリングには尿中・毛琶中の上 素の化学形斯別定量が有效，溶血性はないと発表された。 平田（九州大）は実験結果はTDAA，TBAの自動酸化 物質によると考えるかという質問に対し，皮下投与につ いてはそうである，等の質疑があった。

J 27. ホウ素（B）上フッ素（F）の複合影響を評価 するための第 1 段階として, ホウ酸ナトりウム一回経口 投与による尿中 B 排泄量および血液中 B 濃度の経時推 移を測定した結果， 24 時間内に $99.5 \%$ の B は尿中に排 泄され，血液中には，投与 2 時間で最高濃度に達した。 大村（九州大）の $\mathrm{B} \cdot \mathrm{F}$ 同時曝露職場の有無の質問に対 し，口ケット推進郕工場であること，香山（産医大）の 骨影響についての質問に対し，BとFは拮抗する，等の 質問があった。

\section{環境}

(悪臭・生物)

H 5. 硫化水素の発生と分析

小笠原真理子（産医研）ほ加

H 6. 作業瞢境の評価管理のための化学物質臭気認知 教育の重要性

星加安之（信大医衛生） 
H 7. 手術時の粉じん䡧露に関する研究一エイズ・B 型及びC 型肝炎の感染への可能性について一

名古屋俊士（早大理工）ほか

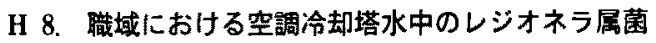
の検出

有馬恵子（新日化環境エンジニア）ほか

座長：土屋博信（名古屋市衛研）

H 5 . 空気中硫化水素索 $1 \mathrm{M} \cdot \mathrm{NaOH}$ に液体捕集後,

電気化学検出器を装着したイオンクロマトグラフィーで 分析する方法を娭討し，5\%以下の変動係数で，ほぼ $100 \%$ の回收率を得た之の報告であった，硫化水素発生 に用いた硫酸由来のイオウの影響や捕集後の安定性（自 治医大・山内）ならひににシアン化物との分離の程度（座 長）について質疑応答が行われた。

H 6 、前報に引き秸き, 講習会に参加した有機, 特化, 酸欠作業主任者および常生管理者 572 名を対象に, 嗅力 等に関する 19 項目のアンケート調查を行い，化学物質 名とそのにおいとの関連づけについての質問で無回答が 多い点を今後の具気謵知教育を行う上で参考になると報 告している，嗅覚閾值は対象によってい異なり，個人差 あ介在する（産医研・松村）との指摘に対し, 演者は緊 急時の物質情報之して奥気認知の必要性を述べた。

H 7 。手術時に発散する骨，組織片等の粉塺濃度およ び形態とマスクの防蝔率を検討するため，3種のマスク を男女各 2 名に装着して模擬実験を行った，電気および アルゴンビームメス作業時には，マスクによって防鹿率 に差があり，短時間でその低下が認められたがエアード リルによる粉歷粒径は大きいため，何れのマスクの除鹿 率も高率を維持した，しかし，手術室の環境を粉應濃度 だけで評価して良いものかという面での検討む必要に思 える.

H 8. 94 年夏期に福岡県内 8 事業所内の開放型冷却 塔水 83 検体のレジオネラ属菌等の調查をし， $48.2 \%$ か ら同属菌を检出した，全体の $60 \%$ 余は厚生省の基準を 満たしているが, $10^{3} \mathrm{CFU} / 100 \mathrm{ml}$ の菌数を検出した地 点が半径 $2 \mathrm{~km}$ 以内に集中していたことを報告している. 同属菌の耐熱性（早大・名古屋）か６６员程度，職域気 中菌数の実態調查（麻布大・中明）は計画中であり, 高 菌数集中化 (倈長) は空気伝播が考えられることが質疑 応答で明らかになった。

(評価・改善)

H16. 作業環境測定結果からみた環境改善の実龍 芦田敏文（神奈川県予防医協）ほか

H17. 化学物斦算の環境および安全衛生に対する情報の システム化

則武咗二(リコー)

H18. 作業室内の乱れ気流と排気フードの吸い込み風

\section{速の関係}

四本久郎（産医研）

H19. BSK 菌によるコンポスト㡀造施設の脱臭効果

福田 覚 (東大医電顕) ほ

座長 : 星加安之（信大医衛生）

H 16. 平成 3-5 年度継綕作業環境測定実施事業場結 果と環境改善についての報告である。講演集改善実施率 についての修正があった，現場指摘事業項目のマニュア ル化についての問（労研一伊藤氏）に対して作業環境湘 定士ごとに一律でなく，規模に応じた改善指導を適用し ているとの回答があった，別に，A 測定，B 測定の実施 状況についての問があり，環境测定としてA 测定を通 常作業として実施し，B 測定は補完的とり扱いと回答が あった。

H 17，化学物質の環境安全融生情報のシステム化の 構築に関する研究報告である。対象物質数, 情報量, 人 手, 活用面についての問（德山ソーダ田島氏）に対して, それぞれ，1000，MSDSでA4 版 5枚，2-3人の回答 があり,さらに活用面についての問（麻布大中明氏）に は, 教育面を重視し, 未端機操作の操作性, 許可の必要 性を重視するとの回答があり, 禁止物質, 発癌性物質, 高分子物質に対する追加の質疑応答があった。

H 18. 実際現場に役立たせるための作業室内の乱れ 気流之排気フードの吸い込み風速の関係についての基礎 的研究の報告である。講演集に報告のない開口部面積を 尺度にした成績の解析について來長よりの問に対して, 風量面と閉口面速度に対して3通りの実験を実施した結 果から環境衛生工学的に有效であるとの回答があった. さらに、モニターとしてのガスと物じん, airborne dust に対象を広げた実験についての質疑応答がなされ た.

H 19， BSK 菌による水産加工排水より生じる加圧浮 上スカム（150t/月）のコンポスト化における実際現場 製造施設の脱臭効果の報告でする。酼化水素に対する有 効性についての問（産医研四本氏）に悪其物質に対する 脱臭効果は対象とならないとの回答があった. BSK 菌 不在のデータについての問（労研伊䋝氏）に電顕データ は観察したが今回は示さず, 有効なデータではないと判 断したと共同発表者回答があり，国の官能試駼動向に訳 された。

\section{物理環境}

\section{（運動器）}

E25. 若年女子就業者の筋骨格系症状の出現要因につ いて

塩屋園むつみ（三越本店）ほか

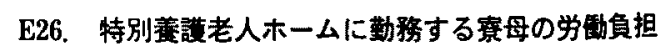


涌井忠昭（宇部短大）ほ加

E27. 障害児学校教員の健康と労謿負担

\section{E28. 䉵護学校教员の健康障害}

垰田和史（滋賀医大予防医学）ほか

武田紀子（東京社医研センター）ほ任

座長：中田 実（淀協社医研）

E 25，百貨店に勤務する 30 歳以下の女性労㗢者につ いて定期健康診断時の問診表により腰痛，局こりの有無 を調查し，筋骨格系症状と生理関連症状との関連につい て検討した報告である.これに対して, 百貨店の勤務時 間延長に伴って筋骨格系の問題が替在化していないか,

27 歳を境に腰痛や局こりが有意に少ない理由として有 症者の退職はないか，症状あり群に対し時々あり之症状 なしを併せて解析した理由は何かなどについて質疑応答 がなされた。

E 26. 特別養護老人ホームで㗢く寮母の労㗢実態につ いて, 日勤之夜勤における勤務時間とその作業内容, 勤 務中の心拍数・歩数およびエネルギー消費量などを測定 した報告である。これに対して，入所者 110 名という規 模に対して寮母 6 名は少ないのではないか，特養にはい くつかの異なる規模の施設があるか調查対象とした施設 の特徵はどうか，夜勤のおむつ交換時間の頻度などにつ いて質疑応答がなされた。

E 27，障害児学校の教員, 事務職員について, 過去 1 年間の䍜患状況, 肩・腕 - 背・腰の自覚症状, 腰痛歴, 自覚的疲労感などの健康状態, 担当児童数などの労憉負 担状況について質問紙法で行なった調查の報告である。

これに対して, 発症者の多い学校や就労 1 年未満で発症 する者の特徽, 就労 1 年末満での発症を防ぐ予防対策の 方法之効果, 就労 2 年目以降に発症する者之の違い, 事 務瞕員で発症する者の特徽などについて質疑応答がなさ れた.

E 28. 筋骨格系の症状のため通院治療を行っている養 護学校教員について, 治療を担当している医療機関から の発症当時の業務負担, 受診契機, 受診時の状况, その 後の療養の経過，職場復掃への過程などに関する臨床経 過報告である、これに対して，職場復婦の段階で行って いるリハビリ就労の内容とその獲得方法, 職場での再 発・多発を防ぐ上で不可欠な職場の改善の具体的方法, 保護者の健康維持などについて質疑応答がなされた。

E29. 幼稚園教諭における婹痛の実態について 鈴木自夫（爱知医大産業保健）ほか

E30. リハビリテーション病娻看護婦の作業分析一座 業医業務を通して

舟越光彦 (九州社医研, 千鳥橋病院) ほか

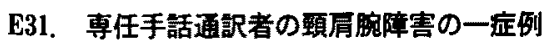

梶山方忠（神戸健康共和会労㗢医研）ほか
E32. 連続手話通訳作業における自覚症状と動作の変 化

北原照代（㴛賀医大予防医学）ほ加 座長：小野雄一郎（名大医衛生）

E 29. 幼稚園教諭の労働を「算調で定型的」と結論づ けている本報告に対して，劳㚪の実態を踏まえていない との意見か会場より出された，又，職場の負荷調查が必 要であるとの意見に対して, 演者より，使用者サイドの 了承を得て現場調查を行なうことは觀しそうだとの回答 があった，さらに，今回の調査を対策によ゙のように生か し得るかや、デー夕処理上「時々あり」を「なし」と して扱うことによる予防対策的結論の歪みについて質問 があった。

E 30. 簡易シーッの具体的な改善内容について会場よ り質問があった，深夜勤務における前須姿勢の割合の增 大に対して, 夜間のみベッド高を $20 \mathrm{~cm}$ 位上昇させる 対策を行なうことが可能か否かとの質問も出された，又， 労災申請事例の出現や鎮痛剂使用者の多さ等の現場の問 題の大きさが，瞕場改善の推進力となったことが報告さ れた. 今後，調査例数を增やし，より一般化できる研究 をめざすことが求められる.

E 31. 手話通訳者の頸肩腕障害症例報告である. 会場 からの質問に対して，本例が労災認定事例であることが 報告された. 又, 手話通訳作業者の全国における労災認 定件数が 6 件（関連事例考含的 7 件）との会場からの発 言があったささらに認定行政関係者にこのような作業で の頸肩腕障害発症に関する情報を知らせることの重要性 が会場より指摘された，今徭，多くの症例をまとめ, 病

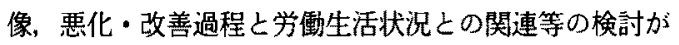
求められる。

E 32. 手話通訳作業負担に関する実験的研究である本 報告に対して，作業中の手首の高さの変化について質問 があった，手の早い動きについて，0.2秒のサンプリン グ間隔では追跡が難しく、今後の課題として取り組みた い旨，報告者より回答があった，又，要医療者を夷験の 対象者としたことについて倫理的側面加ら質問があり， 要医療者に関する作業管理対策確立も目的であったとの 回答がなされた，今後，対策に結合させた一層の検討か 求められる。

E33. 学校給食調理の作業遂行に伴う自覚应状変化 重田博正（淀協社医研）ほ力

E34，学校㭘食調理の作業遂行に伴う自覚症状变化の 関連要因

中田 実（淀協社医研）ほか

E35. 学校給食調理員の変形性手指関節症一健康診断 の分析

田島隆與（松浦診療所）ほか 